\title{
Access to Healthcare and Health Seeking Behaviour among Female Head Porters in Kumasi, Ghana: The Impact on Public Health
}

\author{
Justice Ofori-Amoah ${ }^{1 *}$, Justice Thomas Sevugu ${ }^{2}$, Sheila Ofori-Addai ${ }^{3}$, Emmanuel Nakua ${ }^{4}$, \\ Michael Rockson Adjei ${ }^{5}$ \\ ${ }^{1}$ District Health Directorate Ghana Health Service Sekyere East Effiduase-Ashanti Ghana \\ ${ }^{2}$ Municipal Health Directorate Atwima Nwabiagya Nkawie Ashanti-Ghana \\ ${ }^{3}$ Municipal Health Directorate, Ghana Health Service Ejisu, Ashanti-Ghana \\ ${ }^{4}$ Kwame Nkrumah University of Science and Technology, School of public Health \\ Department of Epidemiology, Ghana \\ ${ }^{5}$ Regional Health Directorate, Ashanti-Ghana
}

\begin{abstract}
Given the nodality of Kumasi, the city attracts migrants from all parts of Ghana into its market space. Notable among such migrants are the female head porters popularly called "Kayayie". As a result of the expensive rents in urban space, female head porters live in kiosks, verandas, and squatters in any available space. This exposes the porters to a myriad of environmental and health risks amidst poor health-seeking behaviour. This study sought to examine access to health and healthseeking behaviour of female head porters in Kumasi. The study adopted quantitative methods in collecting and analyzing data. The primary units of the investigation were female head porters. The study used a sample size of 250 respondents who were interviewed through self-administered questionnaires. Findings show that only $25.2 \%$ of the respondents had access to healthcare, as about 74.8\% lacked access to basic healthcare. The majority of those who had access to healthcare (54\%) go to the health facility by foot, while about $42.9 \%$ access the facility by car. Though $71.4 \%$ of the head porters were subscribers of NHIS, only $25.2 \%$ resort to professional healthcare givers when they are sick. Generally, access to health and health-seeking was poor among the female head porters. The study recommended the expansion of health facilities, especially in poor urban communities, and education on health-seeking among head porters.
\end{abstract}

Keywords: Female head porters, Health seeking behaviour, Health conditions, Migration; Urban poor.

\section{Introduction}

Migration continues to characterize most urban areas, with the majority of people who are susceptible to migration being young adults [1]. Research has argued that one out of every eight migrants are young people within the ages of 15 and 24 years [2].

Young people are always on the move to find greener pastures elsewhere or to secure a livelihood opportunity. Estimates claim that about a quarter of young people desire to migrate to other countries to seek better opportunities [3]. Though external migration is always blamed for the woes of the youth, internal migrations are on the rise and pose threats to the sustainability of both the urban centers that receive these large numbers and the dwindling rural areas which lose these young people [4].

For example, [5] argues that the youth in Africa are always moving as they desire to migrate from rural areas to urban areas in search for better opportunities and greener 
pastures. In this regard, most rural dwellers in Africa, such as Morocco and Ghana, see ruralurban migration as a survival strategy to withstand harsh economic conditions in rural areas $[5 ; 6]$. Some scholars argue that lack of decent opportunities such as education and better livelihood options are responsible for this migration trend, though other factors may play [7; 8]. A myriad of reasons exists for the engagement of women and young girls in head porting [9].

According to [10], most girls who engage in head porting do so because they want to go into an apprenticeship, go back to school, raise capital for future business ventures, take care of their families, or to buy wares for marriage. However, it is worth noting that some head porters had multiple reasons for their involvement in porting. Similar results were also obtained by [11, 12, 13]. Other studies established that lack of education, poverty, and socio-cultural factors accounted for some of the reasons why young female adolescents migrate to the South to engage in head porting popularly called in Ghana 'kayayie' [6].

Research shows that open spaces, platforms at lorry stations, makeshift temporary wooden structures, and stalls serve as abodes for most head porters in Accra [14]. In a study conducted by [15] and [16], young girls engaging in head porting activities face problems such as poor health care, poor housing facilities, inadequate sanitation facilities, and harassment by men at their sleeping places [11]. These findings are supported by [17], who revealed that a decent place to sleep after a hard day's work, lack of safety and security of Kayayei and their belongings, harassment, and exploitation from clients were the problems confronting kayayei.

The poor conditions under which head porters live and work exposes them to health risks and complications [18]. Also, it is established that head porters in Southern Ghana are exposed to psychological problems, physical abuse, and health hazards [14]. [19] posit that poor eating habits and lack of accommodation, harsh working conditions, and lack of knowledge about health conditions exposes head porters to health problems such as skin rashes, cholera, neck pains, stomach ache and malaria.

As a result, [18] found that malaria was a common health challenge amongst female porters. Yet, lack of faith in the National Health Insurance Scheme, financial constraints, and long waiting periods at the health facilities militated against seeking appropriate health care at the hospitals and clinics by female head porters [19]. Access to and utilization of health services has been influenced by the use of the National Health Insurance Scheme. Inability to generate the needed funds to bear the high cost of healthcare service significantly affects the utilization of health [20].

Despite the fact that the health challenges faced by head porters who migrate to the Southern part of Ghana in search of livelihoods, the health-related impacts of their activities have been under-explored. For example, very little is known about health-related issues and the health-seeking behaviour of head porters. Also, the roles of stakeholders in ensuring access to good health and how socially supportive networks developed by porters are used in their health-seeking behaviour have been largely ignored.

Accordingly, this research explores access to health and health-seeking behaviour of female head porters in Kumasi. Rural-urban migration is old in Africa and greatly influences the urbanization pattern to a significant degree. While people migrate from the northern part of Ghana to the southern part in search of economic opportunities, they encounter many challenges [21].

One of these challenges is the poor healthseeking behaviour of head porters [8]. Due to the competitive nature of urban circumstances and the demanding monetary and other returns in professional healthcare services, head porters shirk professional healthcare for selfmedication, herbalists, and other traditional 
methods. Sometimes, some rely on the directions from their spiritual directors the expense of professional healthcare.

Though some of these head porters are aware of the impact of relying on unprofessional healthcare givers, poverty, expensive nature of professional healthcare, lack of available health infrastructure, socio-cultural factors, and or environmental conditions have influenced their health seeking negatively [21].

The impact of seeking unprofessional healthcare is great and has been estimated to be responsible for the death of about $50 \%$ of all patients from developing countries [22]. This raises concerns and makes the subject topic as increasing global concerns on health practices continue to gain center stage in all international and national discourses. This research aims to identify health challenges facing female head porters in Kumasi, identify the health-seeking behaviours and practices of female head porters, and determine the factors influencing head porters' access to health service in Kumasi.

\section{Research Methodology}

This study used a quantitative research design in understanding the access to healthcare and health-seeking behaviour among female head porters in Kumasi. Appropriately, a quantitative method was used in the collection and analysis of data.

The study first sought to understand the reasons for migration, the nature and trend of the migration, and the health-seeking behaviour of female head porters in Kumasi. With the estimated study population of 14,000 female head porters (kayayie people), the sample size of 250 respondents was determined to be surveyed. The sample size was determined through the use of Slovin's formula for the determination of samples. Pre-coded and selfadministered questionnaires were used to elicit data from the respondents. The nature of the questionnaire design included both open-ended and close-ended questions. The questions targeted the socio-economic and cultural characteristics and health-seeking behaviour of female head porters.

The author, therefore, sought administrative clearance from the various stakeholders before embarking on the study. This research was conducted in compliance with the ethical guidelines of the Kwame Nkrumah University of Science and Technology and Komfo Anokye Ethical Review Board. The researcher received positive feedback and was cleared to undertake the study based on the protocols and the data collection instruments presented for approval.

\section{Results of the Study}

\section{Demographic Characteristics of the Study Population}

The mean age of the respondents was 25.06 \pm 7.06 years, with those aged between 20-24 years forming the majority (33.6\%). About $49.6 \%$ of the respondents do not have formal education.

Again, only $0.8 \%$ of those who have formal education obtained WASSCE certificates (Table 1). The remaining respondents have education up to the basic school level. The majority of the respondents were single (50.4\%) with an average monthly income of GHC $253.71 \pm 102.37$. 
Table 1. Socio-demographic Characteristics of Respondents

\begin{tabular}{|c|c|c|}
\hline \multirow[t]{2}{*}{ Variable } & \multicolumn{2}{|l|}{ Head porters } \\
\hline & Frequency $(n=250)$ & Percent (\%) \\
\hline \multicolumn{3}{|c|}{ Age of porter (years) } \\
\hline Mean $( \pm \mathrm{SD})$ & $25.06 \pm 7.06$ & \\
\hline$<20$ & 68 & 27.2 \\
\hline $20-24$ & 84 & 33.6 \\
\hline $25-29$ & 40 & 16.0 \\
\hline $30-39$ & 37 & 14.8 \\
\hline $40-49$ & 21 & 8.4 \\
\hline $50-59$ & 0 & 0.0 \\
\hline $60+$ & 0 & 0.0 \\
\hline \multicolumn{3}{|l|}{ Marital status } \\
\hline Single & 126 & 50.4 \\
\hline Divorced & 89 & 35.6 \\
\hline Married & 35 & 14.0 \\
\hline \multicolumn{3}{|l|}{ Educational status } \\
\hline Not educated & 124 & 49.6 \\
\hline Primary & 86 & 34.4 \\
\hline JHS & 14 & 5.6 \\
\hline SHS & 2 & 0.8 \\
\hline Tertiary & 0 & 0.0 \\
\hline Informal & 24 & 9.6 \\
\hline \multicolumn{3}{|c|}{ Average monthly income } \\
\hline Mean \pm SD & $253.71+102.37$ & \\
\hline GHS $100-199$ & 63 & 25.2 \\
\hline GHS $200-299$ & 78 & 31.2 \\
\hline GHS $300-399$ & 81 & 32.4 \\
\hline GHS $400 \&$ above & 28 & 11.2 \\
\hline
\end{tabular}

Indicatively, findings show that health- access healthcare services. Car was the major seeking behaviour is still poor among means of transport to the healthcare facility by respondents as only $25.2 \%$ of the people almost $42.9 \%$ of the respondents. Therefore, the interviewed have access to healthcare when medical bills, transport costs, and the time spent they are not well (Table 2a). The majority of seeking healthcare services were revealed to be the respondents $(74.8 \%)$ indicated their the major reasons female head porters had low inability to access healthcare in their access to health facilities. Tables 2-4 show the threatening health conditions. Among those results of the study, which were further who accessed healthcare, a majority, 54\%, discussed to inform policy and practice.

walked for about 3-4 hours before they could 
Table 2. Access to Healthcare Services by Female Head Porters in Kumasi

\begin{tabular}{|c|c|c|}
\hline Variable & Frequency $(n=250)$ & Percent (\%) \\
\hline \multicolumn{3}{|l|}{ Access healthcare when need arises } \\
\hline No & 187 & 74.8 \\
\hline Yes & 63 & 25.2 \\
\hline \multicolumn{3}{|l|}{ Walking distance to health facility $(n=63)$} \\
\hline Mean $( \pm$ SD) & $178.33 \pm 66.17$ & \\
\hline$<1$ hour & 3 & 4.8 \\
\hline $1-2$ hours & 22 & 34.9 \\
\hline 2-3 hours & 4 & 6.3 \\
\hline 3-4 hours & 34 & 54.0 \\
\hline \multicolumn{3}{|c|}{ Means of transportation to health facility $(n=63)$} \\
\hline Car & 27 & 42.9 \\
\hline Bicycle & 3 & 4.8 \\
\hline Motor cycle & 24 & 38.1 \\
\hline By foot & 9 & 14.3 \\
\hline \multicolumn{3}{|l|}{ Mode of payment of health services $(n=63)$} \\
\hline National Health Insurance Scheme (NHIS) & 45 & 71.4 \\
\hline On credit (Pay later) & 8 & 12.7 \\
\hline Pay as you go & 10 & 15.9 \\
\hline \multicolumn{3}{|c|}{ Properly attended to the last time accessed healthcare services $(n=63)$} \\
\hline No & 13 & 20.6 \\
\hline Yes & 50 & 79.4 \\
\hline \multicolumn{3}{|l|}{ Reason for visiting health facility $(n=63)$} \\
\hline Assured of being treated & 28 & 44.4 \\
\hline Best place for ill health treatment & 11 & 17.5 \\
\hline National health insurance & 24 & 38.1 \\
\hline \multicolumn{3}{|l|}{ Conditions for accessing healthcare $(n=63)$} \\
\hline Boils & 8 & 12.7 \\
\hline Gonorrhea & 9 & 14.3 \\
\hline Malaria & 23 & 36.5 \\
\hline Stomach pains & 15 & 23.8 \\
\hline Wounds & 8 & 12.7 \\
\hline
\end{tabular}

Table 3. Health Seeking Behaviours of Female Head Porters in Kumasi

\begin{tabular}{|l|l|l|}
\hline Variable & Frequency $(\mathbf{n = 2 5 0})$ & Percent (\%) \\
\hline \multicolumn{2}{|l|}{ Last time of feeling sick } & 24.8 \\
\hline 1 month & 62 & 29.6 \\
\hline 2 months & 74 & 26.0 \\
\hline $3-5$ months & 65 & 19.6 \\
\hline 6 months & 49 & 11.6 \\
\hline Place medical services was sought & 36.4 \\
\hline Hospital & 29 & 30.4 \\
\hline Herbalist & 91 &
\end{tabular}




\begin{tabular}{|l|l|l|}
\hline Self-medication & 54 & 21.6 \\
\hline Practice of family planning & 99.2 \\
\hline No & 248 & 0.8 \\
\hline Yes & 2 & 11.2 \\
\hline Place of delivery & \multicolumn{2}{|l|}{} \\
\hline Home & 28 & 13.2 \\
\hline Hospital & 33 & 16.4 \\
\hline TBA & 41 & 59.2 \\
\hline Never given birth & 148 & \\
\hline Number of ANC visits (n=102) & 63.7 \\
\hline No ANC visits & 65 & 15.7 \\
\hline$<4$ visits & 16 & 20.6 \\
\hline $4+$ visits & 21 & \\
\hline Vaccination of child (n=102) & 91.2 \\
\hline No & 93 & 8.8 \\
\hline Yes & 9 & 98.0 \\
\hline Knowledge of first aid & 245 & 2.0 \\
\hline No & 5 & 98.4 \\
\hline Yes & 246 & 1.6 \\
\hline Availability of first aid at home & \\
\hline No & 4 & \\
\hline Yes & \\
\hline
\end{tabular}


Table 4. Factors Influencing Female Head Porters' Access to Health Services in Kumasi

\begin{tabular}{|c|c|c|c|c|c|c|c|}
\hline \multicolumn{8}{|c|}{ Access to healthcare } \\
\hline \multirow[t]{2}{*}{ Variables } & No & Yes & Total & \multirow[t]{2}{*}{$\chi^{2}$} & \multirow{2}{*}{$\begin{array}{l}p \text { - } \\
\text { value }\end{array}$} & \multirow[t]{2}{*}{ COR [95\% CI], p-value } & \multirow[t]{2}{*}{ AOR [95\% CI], p-value } \\
\hline & $n=187(\%)$ & $n=63(\%)$ & $\mathbf{N}=(\%)$ & & & & \\
\hline \multicolumn{8}{|l|}{ Age (years) } \\
\hline$<20$ & $58(31.0)$ & $10(15.9)$ & $68(27.2)$ & & & & \\
\hline $20-24$ & $64(34.2)$ & $20(31.7)$ & $84(33.6)$ & & & $1.81[0.78-4.19] 0.164$ & $1.22[0.29-5.22] 0.784$ \\
\hline $25-29$ & $29(15.5)$ & $11(17.5)$ & $40(16.0)$ & & & $2.20[0.83-5.78] 0.109$ & $1.16[0.19-7.01] 0.873$ \\
\hline $30-34$ & $29(10.2)$ & $8(12.7)$ & $27(10.8)$ & & & $2.44[0.84-7.08] 0.100$ & $1.54[0.16-14.63] 0.703$ \\
\hline $35+$ & $17(17.1)$ & $14(22.2)$ & $31(12.4)$ & 11.00 & 0.027 & $4.78[1.80-12.66] 0.002$ & $5.88[0.28-121.32] 0.252$ \\
\hline \multicolumn{8}{|l|}{ Native region } \\
\hline North East & $40(21.4)$ & $19(30.2)$ & $59(23.6)$ & & & & \\
\hline Northern & $70(37.4)$ & $24(38.1)$ & $94(37.6)$ & & & $0.72[0.35-1.48] 0.372$ & $1.63[0.45-5.88] 0.455$ \\
\hline Savanna & $14(7.5)$ & $9(14.3)$ & $23(9.2)$ & & & $1.35[0.50-3.68] 0.553$ & $2.60[0.40-16.95] 0.319$ \\
\hline Upper East & $31(16.6)$ & $6(9.5)$ & $37(14.8)$ & & & $0.41[0.14-1.14] 0.088$ & $0.07[0.01-0.97] 0.047$ \\
\hline Upper West & $32(17.1)$ & $5(7.9)$ & $37(14.8)$ & 8.17 & 0.085 & $0.32[0.11-0.98] 0.045$ & $0.30[0.05-1.90] 0.201$ \\
\hline \multicolumn{8}{|l|}{ Marital status } \\
\hline Single & $103(55.1)$ & $23(36.5)$ & $126(50.4)$ & & & & \\
\hline Divorced & $55(29.4)$ & $34(54.0)$ & $89(35.6)$ & & & $2.77[1.49-5.16] 0.001$ & $2.24[0.44-11.32] 0.328$ \\
\hline Married & $29(15.5)$ & $6(9.5)$ & $35(14.0)$ & 12.41 & 0.002 & $0.93[0.34-2.49] 0.880$ & $4.54[0.94-21.80] 0.058$ \\
\hline \multicolumn{8}{|l|}{ Educational status } \\
\hline Not educated & $93(49.7)$ & $31(49.2)$ & $124(49.6)$ & & & & \\
\hline Primary & $70(37.4)$ & $16(25.4)$ & $86(34.4)$ & & & $0.69[0.35-1.34] 0.287$ & \\
\hline JHS & $9(4.8)$ & $5(7.9)$ & $14(5.6)$ & & & $1.72[0.56-5.29] 0.346$ & \\
\hline SHS & $0(0.0)$ & $2(3.2)$ & $2(0.8)$ & & & $14.84[0.69-17.51] 0.084$ & \\
\hline Informal & $15(8.0)$ & $9(14.3)$ & $24(9.6)$ & 10.67 & 0.031 & $1.82[0.74-4.49] 0.194$ & \\
\hline \multicolumn{8}{|l|}{ Residence } \\
\hline Rented apartment & $11(5.9)$ & $13(20.6)$ & $24(9.6)$ & & & & \\
\hline
\end{tabular}




\begin{tabular}{|c|c|c|c|c|c|c|c|}
\hline Container/Kiosk & $123(65.8)$ & $38(60.3)$ & $161(64.4)$ & & & $0.26[0.11-0.63] 0.003$ & $0.43[0.06-2.99] 0.398$ \\
\hline Ghato & $53(28.3)$ & $12(19.1)$ & $65(26.0)$ & 12.47 & 0.002 & $0.19[0.07-0.53] 0.001$ & $0.28[0.03-2.88] 0.285$ \\
\hline \multicolumn{8}{|l|}{ Family size } \\
\hline$<10$ & $17(9.1)$ & $5(7.9)$ & $22(8.8)$ & & & & \\
\hline $10-14$ & $74(39.5)$ & $32(50.8)$ & $106(42.4)$ & & & $1.47[0.50-4.33] 0.484$ & \\
\hline $15-19$ & $48(25.7)$ & $9(14.3)$ & $57(22.8)$ & & & $0.64[0.19-2.17] 0.471$ & \\
\hline $20+$ & $48(25.7)$ & $17(27.0)$ & $65(26.0)$ & 4.18 & 0.243 & $1.20[0.38-3.77] 0.749$ & \\
\hline \multicolumn{8}{|c|}{ Sex of household head (home) } \\
\hline Female & $36(19.3)$ & $10(15.9)$ & $46(18.4)$ & & & & \\
\hline Male & $151(80.7)$ & $53(84.1)$ & $204(81.6)$ & 0.36 & 0.550 & $1.26[0.58-2.72] 0.550$ & \\
\hline \multicolumn{8}{|c|}{ Household head was a porter } \\
\hline No & $165(88.2)$ & $50(79.4)$ & $215(86.0)$ & & & & \\
\hline Yes & $22(11.8)$ & $13(20.6)$ & $35(14.0)$ & 3.08 & 0.079 & $1.95[0.92-4.15] 0.083$ & $3.78[0.87-16.32] 0.075$ \\
\hline \multicolumn{8}{|l|}{ Number of children } \\
\hline None & $122(65.2)$ & $26(41.2)$ & $148(59.2)$ & & & & \\
\hline One & $19(10.2)$ & $13(20.6)$ & $32(12.8)$ & & & $3.21[1.41-7.31] 0.005$ & $1.61[0.30-8.62] 0.580$ \\
\hline Two & $23(12.3)$ & $12(19.1)$ & $35(14.0)$ & & & $2.45[1.08-5.54] 0.032$ & $0.74[0.10-5.66] 0.775$ \\
\hline $3+$ & $23(12.3)$ & $12(19.1)$ & $35(14.0)$ & 11.68 & 0.009 & $2.45[1.08-5.54] 0.032$ & $0.14[0.01-2.88] 0.205$ \\
\hline \multicolumn{8}{|l|}{ Monthly income } \\
\hline GHS 100-199 & $54(28.9)$ & $9(14.3)$ & $63(25.2)$ & & & & \\
\hline GHS $200-299$ & $59(31.5)$ & $19(30.2)$ & $78(31.2)$ & & & $1.93[0.81-4.63] 0.140$ & $1.97[0.46-8.53] 0.362$ \\
\hline GHS $300-399$ & $58(31.0)$ & $23(36.5)$ & $81(32.4)$ & & & $2.38[1.01-5.59] 0.047$ & $0.91[0.23-3.56] 0.893$ \\
\hline GHS 400 and above & $16(8.6)$ & $12(19.0)$ & $28(11.2)$ & 9.08 & 0.028 & $4.50[1.61-12.59] 0.004$ & $1.06[0.19-5.93] 0.948$ \\
\hline \multicolumn{8}{|l|}{ Insurance status } \\
\hline No & $152(81.3)$ & $10(15.9)$ & $162(64.8)$ & & & & \\
\hline Yes & $35(18.7)$ & $53(84.1)$ & $88(35.2)$ & 88.39 & $<0.001$ & $23.02[10.67-49.67] 0.001$ & $4.62[1.51-14.16] 0.007$ \\
\hline \multicolumn{8}{|c|}{ Place of medical services } \\
\hline Hospital & $0(0.0)$ & $29(46.0)$ & $29(11.6)$ & & & & \\
\hline Herbalist & $91(48.7)$ & $0(0.0)$ & $91(36.4)$ & & & $0.01[0.00-0.01]<0.001$ & $0.01[0.00-0.04]<0.001$ \\
\hline
\end{tabular}




\begin{tabular}{|l|l|l|l|l|l|l|l|}
\hline Pharmacy & $48(25.7)$ & $28(44.4)$ & $76(30.4)$ & & & $0.01[0.00-0.17] 0.001$ & $\mathbf{0 . 0 3}[\mathbf{0 . 0 0}-\mathbf{0 . 4 7}] \mathbf{0 . 0 1 2}$ \\
\hline Self-medication & $48(25.7)$ & $6(9.5)$ & $54(21.6)$ & $\mathbf{1 2 7 . 8 9}$ & $<\mathbf{0 . 0 0 1}$ & $0.01[0.00-0.04]<0.001$ & $\mathbf{0 . 0 1}[\mathbf{0 . 0 0}-\mathbf{0 . 1 1}]<\mathbf{0 . 0 0 1}$ \\
\hline Source of drinking water \\
\hline Ghana Water Company & $60(32.1)$ & $32(50.8)$ & $92(36.8)$ & & & & \\
\hline Open Market & $47(25.1)$ & $15(23.8)$ & $62(24.8)$ & & & $0.60[0.29-1.23] 0.164$ & $2.45[0.67-8.89] 0.175$ \\
\hline Well & $80(42.8)$ & $16(25.4)$ & $96(38.4)$ & $\mathbf{8 . 2 2}$ & $\mathbf{0 . 0 1 6}$ & $0.38[0.19-0.75] 0.005$ & $1.02[0.30-3.44] 0.972$ \\
\hline Access to home first aid \\
\hline No & $487(100.0)$ & $59(93.6)$ & $246(98.4)$ & & & & \\
\hline Yes & $0(0.0)$ & $4(6.4)$ & $4(1.6)$ & $\mathbf{1 2 . 0 7}$ & $\mathbf{0 . 0 0 1}$ & $28.36[1.50-534.48] 0.026$ & $1.47[0.03-73.16] 0.845$ \\
\hline
\end{tabular}

Significant difference. $\alpha<0.0$ 


\section{Discussion of Findings}

Access to healthcare is fundamental for the development of any economy. The revealing findings of only $25.2 \%$ having access to healthcare among the respondents could be disastrous for the health and wellbeing of the female head porters. However, this finding corroborates an earlier study conducted in Accra by [23], who found that only $25 \%$ of the head porters have access to healthcare services from health facilities. The current study showed that $74.8 \%$ of the female head porters surveyed did not have access to healthcare services due to limited income and other socio-cultural circumstances. Our findings also corroborate studies by [24] and [21] that low income and socio-cultural barriers are a hindrance to healthseeking among female porters. The implication of this is that female head porters may end up complicating their health situations, thereby posing dangers to their health and wellbeing. Poor access to healthcare among female head porters amidst poor health-seeking behaviour suggests that there is the need for appropriate measures to help promote health-seeking and healthy living among the head porters.

The findings from the study also revealed that the majority of the female head porters in Kumasi $(74.8 \%)$ do not have access to health facilities when they are sick. Again, among those who had access to healthcare, some had to delay for about a year in order to raise the needed income to attend healthcare. This confirms similar findings from leprosy patients in Ethiopia, who had to wait for one year before accessing healthcare [25]. The implication is that the medical conditions of some of these people may be worse off before they get access to healthcare services. Others delayed in accessing medical care because they had to walk for long distances in order to access healthcare services. This study in that regard validates the findings by [18] that many poor female head porters had to walk for long distances before getting physical access to healthcare. This implies that some patients' conditions may be worsened as a result of the delay in reaching medical centres. This can result in a fatality or exacerbated complications with enormous for public health and wellbeing.

There is inadequate access to and utilization of healthcare services. As asserted by [20], the inability to generate the needed funds to pay the high cost of healthcare services significantly affects the health-seeking of the female head porters. This could have accounted for the low access to healthcare $(25.2 \%)$ in this study. [21] also found that the majority of the head porters are aware of the existence of a health facility around their residence, although most of them seek healthcare outside formal health facilities. Regarding the factors that influenced the head porter's access to healthcare, our findings revealed that female head porters from the Upper East region were 93\% less likely to access healthcare compared to those from the North East region (Table 4). Female head porters with NHIS subscriptions were also 4.62 times more likely to access healthcare as compared to those without NHIS. Clearly, NHIS makes a difference in access to healthcare provision and can influence healthseeking among female head porters.

Although NHIS is known to cut down the cost of medical expenses, some concerns raised were that the scheme could not offer good quality healthcare [26]. Similarly, [23] found that access to and utilization of healthcare services is significantly influenced by the use of NHIS. Though the majority of the female head porters $(71.4 \%)$ were subscribers of NHIS, only a few of them could renew and utilize their NHIS for healthcare services. This finding agrees with [26], who postulate that the Ministry of Gender, Children and Social Protection enrolled the vulnerable, including head porters, on the NHIS for free. However, due to their poor income status their preference for traditional medicine, most of these enrollees do not utilize the scheme when they are sick. 
Another factor that significantly influenced healthcare utilization was the seeking of herbalist and pharmacy services. Comparatively, healthcare utilization in professional medicine were lower as head porters who sought medical services from Herbalist, Pharmacy, and self-medication. About one-third of these head porters sought herbalists when they needed medical services, whiles quite a proportion also utilized pharmacy or practiced self-medication. This confirms findings of [27] that the popular means of seeking healthcare by head porters was purchasing drugs from pharmacies or drug peddlers instead of professional healthcare givers.

Health challenges facing head porters were also assessed in this current study. Malaria was a major health condition faced by most of the head porters. This confirms earlier studies conducted in Accra by [19], who found malaria as one of the health-related concerns among head porters. Similarly, [18] found out that malaria was a common health challenge amongst female porters. Other health conditions experienced by female head porters in Kumasi include general body pains, typhoid fever, boils, gonorrhea, and wounds. General body pains experienced by these head porters may be attributed to the heaviness of the loads they carry and the distance they cover carrying the loads. A study conducted by [18] found out that the goods carried by head porters were very heavy.

\section{Recommendations}

The research recommended the following for policy and practice based on the findings of the study.

First of all, there is the need for educational campaigns throughout the areas occupied by these head porters to educate them on the need for professional medical care and the importance of health-seeking. This educational campaign should extend to the general citizenry to educate and inform them on the need to maintain the health of the body and soul. In addition, the government should establish healthcare centers in and around slum areas usually occupied by these migrant women and children. Again, social interventions programs should not only register head porters and other urban poor free but make allowance for free premium renewal. This will encourage them to seek professional healthcare. More healthcare facilities should also be established to ensure that facilities are available for all. This will reduce the time and distance covered to access health needs. Lastly, as a behavioural trait, the head porters need cultural orientation on the need for professional medical attention irrespective of one's beliefs. These will help improve the health-seeking among female head porters and generally contribute to improved healthcare delivery.

\section{Conclusion}

Access to health and health-seeking behaviour among female head porters in Kumasi is low. Head porters continue to face a myriad of challenges, such as a poor living environment which worsens their health conditions. Again, due to prejudice and perceptual biases, most female head porters resort to traditional medical treatment to neglect of professional healthcare. As a result, the female head porters are not able to make good use of the National Health Insurance Scheme even upon free initial registration. This is because many of them could not get the needed funds to renew their subscription to the NHIS. Basic problems in healthcare provision continue to exist around migrant communities and Zongos, where most of the female head porters live. It is recommended that educational campaigns in addition to infrastructural provision, will help increase the health-seeking behaviour of female head porters. Also, intensification of social vulnerability interventions can help ameliorate the plight of some of these head porters. 


\section{Acknowledgement}

The author thanks the almighty God for the gift of wisdom, knowledge, and insight in completing this study. Secondly, the author is grateful to the anonymous supervisors who spent every effort to make sure this work was complete. Lastly, the author's thanks all anonymous reviewers for their valuable insights in enriching this work.

\section{References}

[1] Awumbila, M., Kofi Tehe, J., Litchfield, J., Boakye-Yiadom, L., Deshingkar, P. \& Quartey, P. (2015). Are migrant households better off than nonmigrant households? Evidence from Ghana. Migration Out of Poverty Working Paper No. 28.

[2] UNICEF (2007). The impact of international migration: children left behind in selected countries of Latin America and the Carribean, Division of policy and planning, working paper. University of Ghana http://ugspace.ug.edu.gh.

[3] Deshingkar, P. \& Grimm, S. (2005) Voluntary internal migration: An update. Overseas Development Institute.

[4] Owusu, L., \& Yeboah, T. (2018). Living conditions and social determinants of healthcare inequities affecting female migrants in Ghana. GeoJournal, 83(5), 1005-1017.

[5] Tufeiru, A. (2014). The Nexus of Female Capital and North-South Labor Migration in Ghana: A Potential Remedy from Microfinance. Journal of Developing Societies (Sage Publications Inc.), 30(1), 91-114. https://doi.org/10.1177/0169796X13504680.

[6] Awumbila, M., Manuh,T. Quartey, P., Bosiakoh, T.A and Tagoe, C.A. (2011a) Migration and Mobility in Ghana: Trends, Issues and Emerging Research Gaps. Woeli Publishing: Accra.

[7] Creswell, J.W. (2009). Research Design: A Qualitative, Quantitative, and Mixed Method Approaches. Los Angeles: SAGE Publication.

[8] Owusu, A. (2012). The Living Conditions of Female Head Porters in the Kumasi Metropolis, Ghana.

\section{Funding}

No external funding was received for this study. The researchers themselves covered all costs related to this research.

\section{Competing interests}

The authors declare that they have no competing interests.

https://www.researchgate.net/publication/256932927

[9] Otieku, E., Ackah, C. G., \& Forkuor, D. (2017). Motivations, income determinants and livelihood vulnerability of female teenage head porters in Kasoa, Ghana. International Journal of Social Economics, $\quad 44(12), \quad 2396-2408$. https://doi.org/10.1108/IJSE-10-2016-0286.

[10] Azumah, F. D. \& Onzaberrugu J. N. (2018). The Lifestle of female head porters: the single mother and her coping strategies at Aboabo, Kumasi. International Journal of Innovation Education and Research 6(2).

[11] ILO (2014). World of work report: Developing with jobs.

[12] Kwankye, S.O., Anarfi, J. K., Tagoe, (2011) Migration Impacts within the West African SubRegion. Unpublished paper prepared for the Research Programme Consortium (RPC) on Migrating out of poverty. Brighton: University of Sussex.

[13] Wilson, A. (2012). Resources for Thriving among Female porters in Accra. A Qualitative study of Migrants from Northern Ghana to Greater Accra Region. A Salutogenic Approach. Retrieved from https://bora.uib.no/handle/1956/5879.

[14] Shamsu-Deen, Z. (2013). Migration and Health Nexus: A Case of Female Porters (Kayayei) in Accra, Ghana. Research on Humanities and Social Sciences, 3(3), 103-109.

[15] Nyarko, S. H., \& Tahiru, A. M. (2018). Harsh Working Conditions and Poor Eating Habits: Health-Related Concerns of Female Head Porters (Kayayei) in the Mallam Atta Market, Accra, Ghana. 
BioMed Research International, 2018, 1-7. https://doi.org/10.1155/2018/6201837.

[16] Shamsu-Deen, Z., \& Adadow, Y. (2019). Health-seeking behaviour among migrant female head porters in the City of Accra, Ghana. Ghana Journal of Development Studies, 16(2), 138-156156. https://doi.org/10.4314/gjds.v16i2.7.

[17] Opare, J. A. (2003). Kayayei: The women head porters of southern Ghana. Journal of Social Development in Africa, 18(2). https://doi.org/10.4314/jsda.v18i2.23825.

[18] Awumbila, M. and Ardayfio-Schandorf, E (2008). Gendered poverty, migration and livelihood strategies of female porters in Accra, Ghana, Norwegian journal of Geography, 62(3):171-179.

[19] Montgomery, M., R. (2009). Urban poverty and health in developing Countries. Population Bulletins Vol. 64, No.2. Stony Brook University.

[20] Owusu, G., Agyei-Mensah, S. and Lund, R. (2008). Slums of hope and slums of despair: Mobility and livelihoods in Nima, Accra, Norsk Geografisk Tidsskrift, 62:180-190.

[21] Owusu-Ansah, J. K., \& Addai, M. (2016). Coping with life in a squatter settlement: The case of migrant women in Kumasi, Ghana. Journal of Science and Technology, 33(3).

[22] Awumbila, M., \& Ardayfio-Schandorf, E. (2008). Gendered poverty, migration and livelihood strategies of female porters in Accra, Ghana. Norwegian Journal of Geography, 62(3), 171-179. https://doi.org/10.1080/00291950802335772.

[23] Potts, D. (2008). Recent trends in rural-urban and urban-rural migration in sub-Saharan Africa: The empirical evidence and implications for understanding urban livelihood insecurity. Paper No. 6, Department of Geography, King's College London.

[24] Kwankye, S.O., Anarfi, J. K., Tagoe, C. A., and Castaldo, A. (2009) Independent North-South Child Migration in Ghana: The Decision-making Process. Migration DRC Working Paper T29.

[25] Assesfa A., Nash, J., Tefera Tamiru, \& Byass, P. (2000). Patterns of health seeking behavior amongst leprosy patients in the former Shao province. Ethiop. J. Health Dev.14(1):43- 47.

[26] Owusu, L. \& Yeboah, T. (2017). Living conditions and social determinants of healthcare inequalities affecting female migrants in Ghana. Geo Journal.

[27] Agarwal, S., Attah, M., Apt, N., Grieco, M., Kwakye, E. A., \& Turner, J. (1997). Bearing the weight: The kayayoo, Ghana's working girl child. International Social Work, 40(3), 245-263. https://doi.org/10.1177/002087289704000302. 